\title{
RNA-Directed RNA Polymerase
}

National Cancer Institute

\section{Source}

National Cancer Institute. RNA-Directed RNA Polymerase. NCI Thesaurus. Code C17105.

An enzyme that catalyzes the template-directed addition of ribonucleotides to the 3 ' end of a growing RNA chain. The enzyme utilizes single-stranded RNA as a template. 